\title{
The Influence of Islamic Religious Education and The Intensity of The Use of Gawai Towards Religion Moderation
}

\author{
Qowaid ${ }^{1}$, Supriyadi ${ }^{2}$, Murtadlo $^{3}$, Ayu Nurul Amalia ${ }^{4}$ \\ \{qowaidbmasyhuri@gmail.com ${ }^{1}$, supriyadiesbe@gmail ${ }^{2}$, tadho25@gmail.com ${ }^{3}$, \\ ayunurulamalia.ana@gmail.com ${ }^{4}$ \} \\ IAI Nasional Laa Roiba, Bogor, Jawa Barat, Indonesia ${ }^{1}$ \\ STKIP Panca Sakti, Kota Bekasi, Jawa Barat, Indonesia ${ }^{2,4}$ \\ Puslitbang Pendidikan Agama dan Keagamaan, Jakarta, Indonesia ${ }^{3}$
}

\begin{abstract}
Religious moderation is the way we moderate religion. This study reveals the influence of Islamic religious education (PAI) and the intensity of the use of devices for religious moderation. This research is survey research, the population of state madrasah students in Jakarta. using random sampling techniques, valid and reliable instruments, analysis using multiple regression. Religious moderation is influenced by PAI and the intensity of the use of devices with the equation $\mathrm{Y}=-19,863+1,014 \mathrm{X} 1+-0,021 \mathrm{X} 2$, religious moderation is influenced by PAI, religious moderation is not influenced by the intensity of the use of devices and the influence of PAI and the intensity of the use of devices together with religious moderation. The coefficient of determination of the influence of PAI and the intensity of the use of joint devices for religious moderation is $99.60 \%$.
\end{abstract}

Keywords: Islamic Religious Education, Intensity of Use of Gawai, Religious Moderation

\section{Introduction}

Globalization, as well as nationalism, is a multi-faced concept. It also substantially contains the opposite spirit. Nationalism in the spirit of exclusivity requires loyalty to the nation and state.

Islamic education which has a function as a medium for the formation of morality, ethics, or character of students can be used as an alternative solution to prevent and even eliminate acts of terrorism that arise as a result of Islamic radicalism movements.

Almost every individual ranging from children to parents now have a cellphone or smartphone. Of course, this has not only happened without reason because the current consumption and needs of the people are very different compared to the past few decades. Now the need for communication and information is the most important thing for all people, plus the ease of accessing various features offered by service providers from the smartphone manufacturer itself and various supporting providers. Gawai has interesting features offered and often makes children quickly familiar with it.

Nowadays the spread of information/hoaxes is becoming more widespread. The Mastel Survey (2017) revealed that people receive hoaxes more than once a day. The most widely 
used channel in hoax distribution is social media. The phenomenon of hoaxes in Indonesia raises doubts about the information received and confuses the public. This is used by those who are not responsible for instilling slander and hatred.

Many positive benefits are obtained from the use of devices as stated by psychologist Hadiwidjodjo, Psi (2014), namely: "Simplifying Communication. Gawai is one tool that has sophisticated technology. So everyone can easily communicate. Building children's creativity (Gawai provides a variety of information that can also encourage children to be more creative). Children will find it easier to find all the information and news needed by them, especially in terms of learning while playing or playing while learning. At this age, children are still in an exciting time to play. But do not break away from a learning process that also must be done ". The results of another study conducted by Novan Ardy Wiyani (2015) with the title "Anti-terrorism-based Islamic religious education in high school" This study concluded that to ward off terrorism in high school, the participation of PAI teachers was needed.

Research conducted by Christiany Juditha (2018) with the title "Hoax Communication Interaction in Social Media and Anticipation of Hoax Communication Interactivity in Social Media and Anticipation" results of this study conclude that communication interactions are built very dynamically. The sender or recipient of a hoax message is a party that does not like the government. Other recipients of the message are also those who disagree and deny the hoax as support for the government.

The above studies reveal the positive side of the device, the influence of Islamic religious education in counteracting terrorism and other studies reveal social media as a medium for spreading false news (HOAX). This study reveals the influence of Islamic religious education taught by teachers as education and also balances the information obtained by students from the devices they have on religious moderation in Indonesia. This study raises the title: "The Influence of Islamic Religious Education and the Intensity of the Use of Gawai Against Religious Moderation in students of Madrasah Aliyah Negeri 2 East Jakarta".

This study aims to uncover: 1) Is there an influence of Islamic Religious Education on Religious Moderation, 2) Is there an influence on the Use of Gadgets on Religious Moderation, 3) Is there an Effect of Islamic Religious Education and the Intensity of Use of Gadgets Together Against Religious Moderation.

Moderate in the sense of "balanced" and does not exceed the limits of the naturalness of humanity. In all aspects of its teachings, Islam is characterized by "moderate" (moderate). Religious moderation according to Lukman Hakim (2018) Religious moderation is the way we moderate religion, as opposed to extremes.

Muhammad Ilyasin (2019) Moderation is the core teachings of Islam. Moderate Islam is a religious understanding that is very relevant in the context of diversity in all aspects, both religion, customs, ethnicity and the nation itself.

Ma'ruf (2015) Gawai is a small technological object (tool or electronic item) that has a special function but is often associated as an innovation or new item. The device is always interpreted to be more unusual or more cleverly designed than the normal technology at the time of its discovery.

The intensity of the use of the device can be seen from how often the child uses the device in one day or if seen from every week based on how many days a week a student uses a device.

Nationalism in the spirit of exclusivity requires loyalty to the nation and state. Nationalism, in whatever form tries to convince a nation that feels grounded in the same earth, breathes the same air, also drinks water from the same source, namely Bumi Indonesia. To 
love his homeland that gives life as a gift from Allah SWT. So that every form of natural products must be utilized as well as possible for the common welfare as a nation. In the process, Indonesia tries to abandon tribal, religious, racial and linguistic identity for the sake of cooperation to achieve prosperity.

\section{Research methodology}

This research is a quantitative survey research with multiple regression analysis techniques. The research method used in this study is the Kelinger survey method in Sugiyono (2013) states that "Survey research studies large and small population (or unless) by selection and studying samples chosen from the population to discover the relative incident, and distribution, and interrelation of sociological and psychological variables. "

Survey research is research conducted on large and small populations, but the data studied is data taken from a sample of these populations, to find relative events, distribution, and the relationship between sociological and psychological variables. The sampling technique that will be used in this study is Random Sampling, which is a technique for selecting a sample randomly.

The population of this research is all students of Madrasah Aliyah Negeri 2 Jakarta. The sampling technique that will be used is Random Sampling. The technical analysis used in this study includes Data description, Prerequisite Tests namely normality and Homogeneity Test data and Hypothesis Testing using Multiple Regression Test.

Research Constellation as follows:

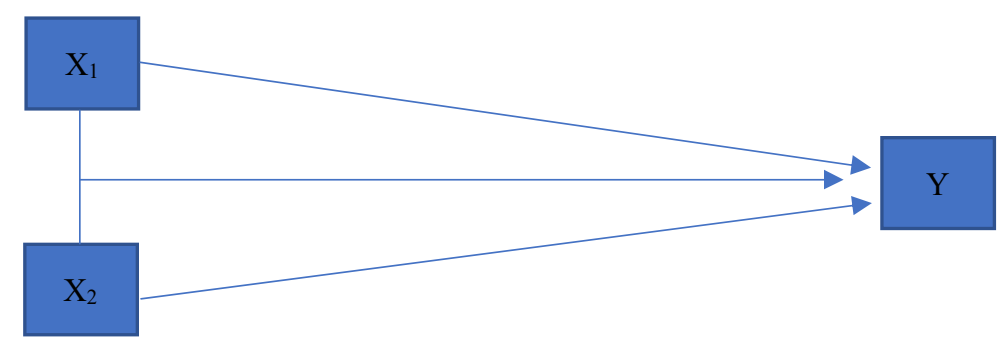

Fig. 1. Research constellation diagram.

Information:

$\mathrm{X} 1$ : Islamic education

X2: Intensity of Gawai Usage

Y: Religious Moderation

An instrument is a tool for measuring about something that is measured.

Three instruments will be used in this study, namely:

1. Students' Perception Instruments About Islamic Religious Education

2. Device Intensity Usage Instrument.

3. Religious Moderation Instruments

Based on the analysis using Microcat ITEMAN software with the same number of samples per group, namely 30 students. Data collection using instruments of student 
perception of Islamic religious education and religious moderation in the form of attitude scale tests. Instruments of student perception of Islamic education are valid and reliable with Alpha reliability of dimension I (aqeedah) 0.674 , dimension II (sharia) of 0.812 , dimension III (morals) of 0.753 and dimension IV (ethics) of 0.839 . The instrument of religious moderation is valid and reliable with Alpha reliability of dimension I (religion) 0.792, dimension II (customs) of 0.831 , dimension III (tribe) of 0.781 and dimension IV (nation) of 0.752.

\section{Reseach result}

The following data analysis results based on the score of religious moderation variables of 250 respondents, obtained the lowest empirical score 25 and the highest empirical score 98, the range of scores 73 , the average score (mean) of 56.34 standard deviation 13.35 , mode 67 , median 56, variance 178,176 and total score 14084 . Islamic religious education variable scores obtained the lowest empirical score of 45 and the highest empirical score of 118, the range of scores 73 , the average score (mean) of 76.28 standard deviations 13.41 , mode 87 , median 76 , variance 179,785 and total score 19070 . The variable score of the Intensity Usage Device obtained the lowest empirical score 24 and the highest empirical score 97, the range of scores 73, the average score (mean) of 55.40 standard deviations 13.29, mode 66, median 55, variance 176,611 and total score 13851 .

Normality test results obtained variable Religious Moderation (Y), Islamic Religious Education (X1), and the intensity of the use of devices (X2) with a normal distribution. Homogeneity test results of the three data groups come from homogeneous groups.

Hypothesis test results are as follows:

1. Double Linear Equations and Test the Significance of Regression Equation Significance. The multiple linear regression equation is $\mathrm{Y}=-19,863+1,014 \mathrm{X} 1+-0,021 \mathrm{X} 2$. Islamic Education Variable (X1) has a positive effect on the Religious Moderation Variable (Y) of students in Madrasah Aliyah Negeri 2 Jakarta. Furthermore, the statistical price for the coefficient of the Variable Usage Intensity (X2) p-value is greater than 0.05 , which means the Variable Intensity Usage (X2) does not affect the Religious Moderation Variable (Y) of students in Madrasah Aliyah Negeri 2 Jakarta.

2. Test the Significance of Multiple Regression Equations, From the analysis results summarized in the ANOVA table p-value smaller than 0.050. It means that there is a linear influence of Islamic religious education variables (X1) and Intensity Variable Usage (X2) with Religious Moderation (Y) Madrasah Aliyah Negeri 2 Jakarta students. This also means that there is a joint (simultaneous) effect of Islamic religious education variables (X1) and the Variable Usage Intensity Variable (X2) on Religious Moderation (Y).Test the Significance of Multiple Correlation Coefficients, The significance test of the multiple correlation coefficient is obtained from the Summary Model table above, it appears that the multiple correlation coefficient $($ Ry.12) $=0.998$ and Fhit $=28,248,012$, and $\mathrm{p}$-value $=0,000<0.050$ Thus, the multiple correlation coefficient between $\mathrm{X} 1$ and $\mathrm{X} 2$ with $\mathrm{Y}$ is meaningful or significant. While the coefficient of determination is shown by $\mathrm{R}$ Square $=0.996$, which implies that $99.60 \%$ of the variability of religious moderation variables (Y) can be explained by Islamic Religious Education variables (X1) and the Device Usage Intensity variable (X2), so it can be concluded that the influence of variables Islamic Religious Education (X1) and the Variable Usage Intensity (X2) variables together against the Religious Moderation variable (Y) of 99.60\%. 
3. Test the Significance of Partial Correlation Coefficients

a. Correlation between X1 and Y by controlling the influence of X2 (ry1.2) From the analysis results in the table above obtained (ry1.2) $=0.574$ and P-Value $=0.000$ $<0.050$ thus, the correlation coefficient between $\mathrm{X} 1$ and $\mathrm{Y}$ by controlling the variable X2 is Significant.

b. Correlation between X2 and Y by controlling the effect of X1 (ry2.1) From the analysis results in the table above obtained (ry2.1) $=-0.024$ and P-Value $=0.707$ $<0.050$ or $\mathrm{H} 0$ accepted. Thus, the correlation coefficient between $\mathrm{X} 2$ and $\mathrm{Y}$ by controlling the $\mathrm{X} 1$ variable is not significant.

\subsection{Interpretation of research results}

To be able to understand the meaning of the results of the research as a whole, the results of the analysis of the research data above can be interpreted as follows:

1. Religious moderation (Y) of students is influenced by Islamic Religious Education variables (X1) and students' Intensity Usage (X2) variables, This can be seen from anava calculations obtained p-value values less than 0.05 thus Ho rejected, regression $Y$ or X1 and X2 is significant or Islamic Religious Education and the Intensity of the Use of the Device have an effect on the Religious Moderation variable of Madrasah Aliyah Negeri 2 Jakarta students, with the equation $\mathrm{Y}=-19,863+1,014 \mathrm{X} 1+-0,021 \mathrm{X} 2$, thus the third hypothesis in research is supported by empirical data.

2. Religious moderation (Y) of students is influenced by Islamic Religious Education variables (X1). It can be seen from the calculation of anava obtained p-value less than 0.05 thus Ho is rejected, regression $\mathrm{Y}$ or $\mathrm{X} 1$ is significant or Education Islamic religion influences the variable of religious moderation of Madrasah Aliyah Negeri 2 Jakarta students, thus the second hypothesis in the study is supported by empirical data

3. Religious moderation (Y) of students is influenced by the variable Intensity of Use of Devices (X2). It can be seen from the calculation of anava obtained p-value greater than 0.05 so that Ho is accepted, Y or X2 regression is not significant or The intensity of the use of the device does not affect the variable of religious moderation in Madrasah Aliyah Negeri 2 Jakarta students, thus the first hypothesis in the study is not supported by empirical data.

\section{Discussion}

From the results of testing the research hypothesis, shows that the working hypothesis of this study can be accepted

1. There is an influence of Islamic Education variable (X1) on the variable of Religious Moderation (Y) Madrasah Aliyah Negeri 2 Students in Jakarta.

2. This is in line with the research of Yunus and Arhanuddin Salim in Al Tadzkiyyah Journal with the research title "The Existence of Islamic Moderation in Islamic Education Learning Curriculum" (2018) The results of the study reveal that students are very vulnerable groups dragged by currents of religious radicalism. A very young and unstable age with burning enthusiasm and a longing to practice religion more kafah 
(comprehensive) make young groups including Muslim students in high school will be the most vulnerable social groups infiltrated and targeted by radical groups that are preaching understanding and religious attitudes that are rigid and tend to be shallow. So that inevitably, Islamic Education has a moral and social responsibility to help find a way out. The inculcation of Islamic moderation values carried out by PAI teachers in Madrasah Aliyah Negeri 2 Jakarta, in general, has similarities, namely through the teaching process in the classroom based on the syllabus, developed again by the teacher concerned, then applied in interacting in the school environment. In instilling the values of religious moderation in students, several things need to be emphasized that the relationship between the Muslim community and non-Muslims both in one State and another State is based on the principle of peace by humanitarian instincts. This is nothing but a mirror of the universality of Islamic teachings as a blessing for all the inhabitants of nature. In the principle of Islamic teachings, there should be no coercion and no more annexation, on the contrary, if Muslims are in an oppressed condition then in this condition maintaining rights and sovereignty is an alternative solution. From the above explanation, it is clear that Islam is a religion of peace and da'wah that upholds freedom of responsibility. Another reflection of the freedom to embrace religion is that Islam fully protects the rights of the dhimmis, ie non-Muslims who have a peace agreement in the Muslim territory.

3. There is no effect of the variable Intensity of the Use of Gawai (X2) on the variable of Religious Moderation (Y) of Madrasah Aliyah Negeri 2 Students in Jakarta.Adolescence is one of the most changing periods of human development. These changes include physical, intellectual, moral, social, emotional and religious changes. The desire to look for self-identity, high curiosity causes teens to try something new. The inner conflict between religious teachings and community norms with the desire that is embedded in adolescents so that psychologically it causes anxiety and tension in him. The results of another study conducted by Novan Ardy Wiyani (2015) with the title "Anti-terrorismbased Islamic religious education in high school" This study concluded that to ward off terrorism in high school, the participation of PAI teachers was needed. Research conducted by Christiany Juditha (2018) with the title "Hoax Communication Interaction in Social Media and Anticipation of Hoax Communication Interactivity in Social Media and Anticipation" results of this study conclude that communication interactions are built very dynamically. The above studies reveal the positive side of the device, the influence of Islamic religious education in counteracting terrorism and other studies reveal social media as a medium for spreading false news (HOAX).

4. There are an influence of Islamic Religious Education (X1) variable and Gawai Usage Intensity (X2) variable on the variable of Religious Moderation (Y) of Madrasah Aliyah Negeri 2 Students in Jakarta. This is in line with the research of Yunus and Arhanuddin Salim in Al Tadzkiyyah Journal with the research title "The Existence of Islamic Moderation in Islamic Education Learning Curriculum" (2018) The results of the study reveal that students are very vulnerable groups dragged by currents of religious radicalism. In instilling the values of religious moderation in students, several things need to be emphasized that the relationship between the Muslim community and non-Muslims both in one State and another State is based on the principle of peace by humanitarian instincts. 


\section{Conclusions}

After the research data is obtained by using a measuring instrument compiled by researchers, then quantitative data analysis is performed, this is done to answer the problem through testing the research hypothesis. From the results of hypothesis testing, the following conclusions can be drawn:

1. Religious moderation (Y) of students is influenced by Islamic Religious Education variables (X1) and students' Intensity Usage (X2) variables, This can be seen from anava calculations obtained $\mathrm{p}$-value values less than 0.05 thus Ho rejected, regression $\mathrm{Y}$ or $\mathrm{X} 1$ and X2 is significant or Islamic Religious Education and the Intensity of the Use of the Device have an effect on the Religious Moderation variable of Madrasah Aliyah Negeri 2 Jakarta students, with the equation $\mathrm{Y}=-19,863+1,014 \mathrm{X} 1+-0,021 \mathrm{X} 2$, thus the third hypothesis in research is supported by empirical data.

2. Religious moderation (Y) of students is influenced by Islamic Religious Education variables (X1). It can be seen from the calculation of anava obtained p-value less than 0.05 thus Ho is rejected, regression $\mathrm{Y}$ or $\mathrm{X} 1$ is significant or Education Islamic religion influences the variable of religious moderation of Madrasah Aliyah Negeri 2 Jakarta students, thus the second hypothesis in the study is supported by empirical data

3. Religious moderation (Y) of students is influenced by the variable Intensity of Use of Devices (X2). It can be seen from the calculation of anava obtained p-value greater than 0.05 so that Ho is accepted, Y or X2 regression is not significant or The intensity of the use of the device does not affect the variable of religious moderation in Madrasah Aliyah Negeri 2 Jakarta students, thus the first hypothesis in the study is not supported by empirical data.

4. The role of Islamic religious education teachers is needed as a facilitator of students in rectifying the narrow understanding of students in understanding Islam, parents should supervise students in accessing social media.

\section{References}

[1] Alder, H. 2001. Boost Your Intelligence, translation of Kristina Prianingsih. Jakarta: Erlangga,

[2] Anwar, S. 2010. Preparation of Psychological Scale. Yogyakarta: Student Library.

[3] Arikunto, S. 2009. Research Management. Jakarta: PT Rieka Cipta.

[4] Atwater. 1993. Expressions of Emotion, The Encyclopedia. USA: Harvard University,

[5] Black, H. C. 1999. Black's Law Dictionary. West Group. 7th Edition.

[6] Bloom, B.S. 1981. Taxonomy of Educational Objective. Handbook I. New York: Xongman Inc.

[7] Briggs, L. J. 1979. Instructional Design Principles and Applications (Englewood cliffs, Newelence and Prentice Hall),

[8] Callahan, J. F. \& Cark, L. H. 1983. Foundation of Education. New York: Macmillan Publishing Co., Inc.

[9] Irwanto. 1997. General Psychology. Jakarta: PT. Gramedia Main Library.

[10] Kadir. 2010. Statistics for Social Sciences Research. Jakarta: PT Rosemata Sampurna.

[11] Kartono, K. 1996. Introduction to Social Research Methodologies. Bandung: CV Mandar Maju.

[12] Kerlinger, F. N. 2006. Behavioral Research Principles. Yogyakarta: Gadjah Mada University Press.

[13] Nazir, M. 1988. Research Methods. Jakarta: Ghalia Indonesia.

[14] Purwanto. N. M. 2003. Educational Psychology. Bandung: PT. Teen Rosdakarya.

[15] Seniati, L. 2006. Experimental Psychology. Jakarta: PT Intan Sejati Klaten.

[16] Surapranata, S. 2003. Analysis, Reporting, and Interpretation of Test Results, Module.

[17] Syah, M. 1995. Educational Psychology A New Approach. Bandung: PT. Teen Rosdakarya. 
[18] Wagner. 1993. Child Psychology Development, Rudi handbook's translation. Jakarta: PT Gramedia.

[19] Winkel W.S. 1987. Educational Psychology and Learning Evaluation. Jakarta: Gramedia.

[20] Woolfolk, A. E. 1993. Educational Psychology. Needham Heights MMA: Allyn and Bacon Inc. 